\title{
Activation of the Human Neutrophil Nicotinamide Adenine Dinucleotide Phosphate (NADPH)-Oxidase by Protein Kinase C
}

\author{
Jane A. Cox, Arco Y. Jeng, Nancy A. Sharkey, Peter M. Blumberg, and Alfred I. Tauber \\ William B. Castle Hematology Research Laboratory, Boston City Hospital; Departments of Medicine and Biochemistry, Boston \\ University School of Medicine, Boston, Massachusetts 02118; and the Molecular Mechanism of Tumor Promotion Section, Laboratory of \\ Cellular Carcinogenesis and Tumor Promotion, National Cancer Institute, Bethesda, Maryland 20205
}

\section{Abstract}

A variety of phagocytosable and soluble agonists stimulate the human neutrophil respiratory burst enzyme, NADPH-oxidase, an activity required for normal microbicidal function. Of these agonists, the phorbol esters, which stimulate diverse systems by their ability to substitute for diacylglycerol to activate protein kinase $\mathbf{C}$ (the major phorbol ester receptor), have now been shown to directly stimulate NADPH-oxidase through this same receptor. Almost $90 \%$ of the specific receptors for phorbol 12,13dibutyrate (PDBu) were found in the cytosol upon subcellular fractionation. The dissociation constant for $\left[{ }^{3} \mathbf{H}\right] \mathbf{P D B u}$ was 1.2 nM. No significant difference was found in the distribution of the receptor between subcellular fractions from resting as compared with phorbol 12-myristate 13-acetate (PMA)-stimulated neutrophils. On the basis of these binding studies, we were able to establish a reconstituted system in which PMA activated dormant NADPH-oxidase in a light membrane fraction when cytosol, NADPH, phosphatidylserine, or phosphatidylinositol and ATP were added. The calcium chelator, EGTA, inhibited the activation, which suggested a requirement for calcium at low concentrations. The half-maximally effective PMA dose was 1.1 $\mathrm{nM}$, as predicted from the receptor content in these preparations. Reconstitution of oxidase activity was rapid, peaking within 1 min of incubation. Purified protein kinase $C$ was able to substitute for the cytosol fraction, and accounted for $80 \%$ of the cytosol activity. These studies demonstrate that phorbol esters stimulate the neutrophil respiratory burst through activation of cytosolic protein kinase $\mathbf{C}$, which in turn activates either a regulatory constitutent or the NADPH-oxidase directly in the plasma membrane to generate an active $\mathrm{O}_{2}^{-}$-generating system.

\section{Introduction}

The human neutrophil undergoes a cyanide-insensitive respiratory burst upon phagocytic stimulation or upon exposure to the soluble agonists phorbol esters, e.g., phorbol 12-myristate 13-acetate (PMA), ${ }^{1}$ and cis-polyunsaturated acids, e.g., arachi-

Address correspondence to Dr. Tauber, FGH-I, Boston City Hospital. Received for publication 28 February 1985 and in revised form 18 July 1985.

1. Abbreviations used in this paper: AA, arachidonic acid; $\gamma$, light membranes; $\beta$, specific granules; $\alpha$, azurophilic granules; DFP, diisopropyl fluorophosphate; OAG, 1-oleoyl-2 acetyl glycerol; PDBu, phorbol 12,13dibutyrate; PI, phosphatidylinositol; PMA, phorbol 12-myristate 13-acetate; PS, phosphatidylserine; $S_{2}$, cytosol; SOD, superoxide dismutase.

J. Clin. Invest.

(c) The American Society for Clinical Investigation, Inc.

0021-9738/85/11/1932/07 \$1.00

Volume 76, November 1985, 1932-1938 donic acid (AA) (1, 2). The enzymatic activity responsible for this respiratory burst is that of the membrane-bound NADPHoxidase (3), which reduces molecular oxygen to superoxide $\left(\mathrm{O}_{2}^{-}\right)$and which constitutes the initiating enzymatic step in the formation of a cascade of reactive oxidizing species. The biochemical sequence of the activation pathway(s) is likely to involve multiple postreceptor steps (3). The stimulation initiated by PMA and AA is of particular interest, as each appears to bypass plasma membrane-mediated receptors through the activation of cytosolic protein kinase $\mathrm{C}$ (sic infra).

We have focused on the activation pathway induced by the phorbol esters. Specific binding studies employing phorbol 12,13dibutyrate $(\mathrm{PDBu})$ quantitatively linked ligand binding to oxidase expression (4). That this neutrophil receptor binding activity was intracellular was suggested initially by the ability of PMA to fully activate the oxidative burst in the presence of impermeant sulfhydryl reactive agents (5) and stilbene disulfonic acids (6), whereas pathways mediated by externally oriented plasma membrane receptors were inhibited. More recently, it has been demonstrated in a variety of tissues that the ubiquitous phorbol ester receptor is protein kinase $C(7,8)$, a cytosolic enzyme which becomes membrane associated upon exposure of cells to phorbol esters. In vitro, the phorbol esters activate protein kinase $C$ in the presence of anionic phospholipids. The relationship of this kinase to protein phosphorylation in the neutrophil has recently been investigated; although preliminary studies have failed to directly link kinase activity to oxidase activation (9-11), correlation of the phosphorylation of a $50,000-\mathrm{mol} \mathrm{wt}$ cytosolic protein with degranulation has been reported with rabbit neutrophils (12). In the current study, we have examined the distribution of the phorbol ester receptor in the subcellular fractions and characterized its binding parameters.

Recently, an activation pathway, possibly parallel to PMA, has been suggested as the mechanism of AA stimulation of the neutrophil respiratory burst (13). In that study, AA stimulated protein kinase $\mathrm{C}$ activity independent of phosphatidylserine (PS), but required diolein and calcium for full expression. It was postulated that AA enhanced the affinity of protein kinase $\mathrm{C}$ for calcium and that AA stimulated the respiratory burst by stimulating protein kinase C. Previous work had established the characteristics of AA stimulation of the intact neutrophil (2), and recent reports have characterized the participation of a soluble cytosolic factor (14-17).

In the current study, we present evidence for a role of protein kinase $\mathrm{C}$ in the activation of NADPH-oxidase. In our in vitro system, PMA activation of the NADPH-oxidase from the plasma membrane subfraction is dependent on anionic phospholipids and a cytosolic factor. The cytosolic factor can be replaced with purified protein kinase $\mathrm{C}$, which indicates its probable identity. These studies then discern the mechanism of PMA activation of the neutrophil respiratory burst through the expression of the protein kinase $\mathrm{C}$ system. 


\section{Methods}

Triton X-100, PMA, PDBu, 1-oleoyl-2-acetyl glycerol (OAG), EGTA, Trizma base, L-phosphatidyl-L-serine, phosphatidylinositol (PI), phosphatidylcholine, phosphatidylethanolamine, cytochrome $c$, superoxide dismutase (SOD), diisopropyl fluorophosphate (DFP), ATP, piperazine$N, N^{\prime}$-bis (2-ethanesulfonic acid), 3-( $N$-morpholino)propanesulfonic acid, bovine serum albumin (fraction V), and NADPH were obtained from Sigma Chemical Co., St. Louis, MO; Dextran T 500, Ficoll-Paque, and Percoll was purchased from Pharmacia Fine Chemicals, Piscataway, NJ. $\left[{ }^{3} \mathrm{H}\right] \mathrm{PDBU}, 13.4 \mathrm{Ci} / \mathrm{mmol}$, was obtained from New England Nuclear, Boston. MA.

Cell isolation and fractionation. Neutrophils from normal human donors were isolated as previously described (18). Cells were incubated with DFP to inhibit serine-proteolytic activity by adding $10 \mu \mathrm{l}$ of a 1.5 $M$ stock solution of DFP to $5 \mathrm{ml}$ of a suspension of the neutrophils in phosphate-buffered saline (PBS) (5) for $5 \mathrm{~min}$ on ice and then washing out the inhibitor by the addition of buffer and centrifugation at $400 \mathrm{~g}$ for $5 \mathrm{~min}$. After resuspension in disruption buffer, the cells were disrupted by nitrogen cavitation and fractionated on Percoll gradients as described in detail previously (18). Neither intact cells nor the NADPH-oxidase harvested from PMA-stimulated human neutrophils treated by the DFP protocol were inhibited relative to control non-DFP exposed cells (data not shown), and parallel experiments with non-DFP-treated cells revealed no differences in oxidase activity when stimulated with either the reconstituted $S_{2}$ system or purified protein kinase $C$ (see below). In binding studies of PMA-stimulated neutrophils, the cells were prewarmed at $37^{\circ} \mathrm{C}$, activated with PMA $(1 \mu \mathrm{g} / \mathrm{ml})$ for $5 \mathrm{~min}$, and then processed in parallel fashion to unstimulated cells as noted above (18).

Assay of neutrophil NADPH-oxidase. NADPH-oxidase activity was measured by the SOD-inhibitable reduction of cytochrome $c$ as described for an unfractionated particulate preparation (4) or by fractions from Percoll gradients (18) as indicated in the text. Reduction of cytochrome $c$ was followed kinetically for 5-10 min, but rates expressed are maximal and occurred within the first $2 \mathrm{~min}$ of the reaction (see Fig. 5). The assay mixture $(1 \mathrm{ml})$ contained $100 \mu \mathrm{M}$ NADPH, $80 \mu \mathrm{M}$ cytochrome $c$, and $100 \mu \mathrm{l}(200-450 \mu \mathrm{g})$ of membranous or soluble neutrophil fractions in potassium phosphate buffer, $0.13 \mathrm{M}, \mathrm{pH}$ 7.0.

To study the protein kinase $\mathrm{C}$ activation of the oxidase, samples of the cytosol fraction $\left(\mathrm{S}_{2}\right)(300-450 \mu \mathrm{g})$ or protein kinase $\mathrm{C}(1 \mathrm{U}=500$ pmol $\mathrm{PO}_{4}^{-}$transferred/min, as described below) were incubated with $\mathrm{CaCl}_{2}$ ( $1 \mu \mathrm{mol})$, magnesium acetate $(5 \mu \mathrm{mol}), \mathrm{Na}_{2} \mathrm{ATP}(50 \mathrm{nmol})$, phospholipid (160 $\mu \mathrm{g}$, unless otherwise stipulated), and PMA (1 ng unless otherwise indicated) at $28^{\circ} \mathrm{C}$ in a total volume of $0.7 \mathrm{ml}$; samples of the $\gamma$-fraction (plasma membrane fraction containing the NADPH-oxidase) were then added (200-300 $\mu \mathrm{g})$ and the mixture incubated for $1 \mathrm{~min}$ (unless otherwise indicated) at $28^{\circ} \mathrm{C}$ in a total volume of $0.8 \mathrm{ml}$. NADPH $(100 \mathrm{nmol})$ and cytochrome $c(80 \mathrm{nmol})$ were then added to the reaction mixture to a total volume of $(1 \mathrm{ml})$, and the SOD-inhibitable reduction of cytochrome $c$ was monitored at $550 \mathrm{~nm}$ at $28^{\circ} \mathrm{C}$ as previously described (4).

Phorbol ester binding. $\left[{ }^{3} \mathrm{H}\right] \mathrm{PDBu}$ binding was assayed for the cytosol (the $S_{2}$ fraction), light membranes ( $\gamma$-fraction), and granules ( $\beta$ - or $\alpha$ fractions) from the Percoll gradient of nitrogen-cavitated neutrophils. $\left[{ }^{3} \mathrm{H}\right] \mathrm{PDBu}$ binding was determined in $250-\mu \mathrm{l}$ incubation mixtures which contained $\left[{ }^{3} \mathrm{H}\right] \mathrm{PDBu}$, neutrophil fractions $\left(20-170 \mu \mathrm{g}\right.$ for $\mathrm{S}_{2}$ and $50-$ $1,700 \mu \mathrm{g}$ for other fractions), $0.05 \mathrm{M}$ Tris-Cl, $\mathrm{pH} 7.4,0.1 \mathrm{mM} \mathrm{CaCl}$, PS at $100 \mu \mathrm{g} / \mathrm{ml}$, nonradioactive phorbol esters where indicated, and bovine gamma globulin at $2-4 \mathrm{mg} / \mathrm{ml}$. In competition experiments, the concentration of free $\left[{ }^{3} \mathrm{H}\right] \mathrm{PDBu}$ at the $\mathrm{ED}_{50}$ was 5-18 $\mathrm{nM}$. For determination of PDBu saturation curves, concentrations of free $\left[{ }^{3} \mathrm{H}\right] \mathrm{PDBu}$ between 0.05 and $30 \mathrm{nM}$ were used. Dilutions of $\left[{ }^{3} \mathrm{H}\right] \mathrm{PDBu}$, nonradioactive phorbol esters, and other inhibitors were made in $0.05 \mathrm{M}$ Tris$\mathrm{Cl}, \mathrm{pH} 7.4$, containing bovine gamma globulin, at a concentration of 10 $\mathrm{mg} / \mathrm{ml}$. Incubations were carried out in $1.5 \mathrm{ml}$ polypropylene Eppendorf micro centrifuge tubes for $30 \mathrm{~min}$ at $37^{\circ} \mathrm{C}$. The samples were then chilled for $5 \mathrm{~min}$ at $0^{\circ} \mathrm{C}, 187 \mu \mathrm{l}$ of $35 \%$ (wt/wt) polyethylene glycol in $50 \mathrm{mM}$ Tris- $\mathrm{Cl}, \mathrm{pH} 7.4$, was added (to bring the final polyethylene glycol concentration to $15 \%$ ), and samples were incubated for $15 \mathrm{~min}$ at $0^{\circ} \mathrm{C}$ to permit precipitation of the proteins. The precipitates were spun down for 15 min at $12,000 \mathrm{rpm}$ in a Beckman microfuge 12 centrifuge at $4^{\circ} \mathrm{C}$. A $100-\mu l$ aliquot of the supernatant was removed and its radioactivity measured to determine the free $\left[{ }^{3} \mathrm{H}\right] \mathrm{PDBu}$ concentration. The remainder of the supernatant was removed by aspiration and blotting with a Kimwipe; the tip of the centrifuge tube was cut off, and the radioactivity in the pellet was measured to determine total bound $\left[{ }^{3} \mathrm{H}\right] \mathrm{PDBu}$. Nonspecific binding was measured in the presence of $30 \mu \mathrm{M}$ nonradioactive PDBu, and the partition coefficient for $\left[{ }^{3} \mathrm{H}\right] \mathrm{PDBu}$ between supernatant and pellet was determined. Specific binding represents the difference between the total and nonspecific binding, where nonspecific binding for each tube was calculated from the partition coefficient of $\left[{ }^{3} \mathrm{H}\right] \mathrm{PDBu}$ and the measured free $\left[{ }^{3} \mathrm{H}\right] \mathrm{PDBu}$ concentration for that tube. In each experiment, each point represents the average of at least triplicate determinations. Each experiment was performed at least twice (see text for actual number). In initial experiments, particulate preparations were also assayed omitting addition of PS and polyethylene glycol. Results were comparable.

Purification of protein kinase $C$. Protein kinase $C$ enzymatic activity was assayed by measuring the incorporation of ${ }^{32} \mathrm{P}$ into histone $\mathrm{H} 1$ from $\left[\gamma-{ }^{32} \mathrm{P}\right] \mathrm{ATP}$. The reaction mixture contained, in a total volume of $50 \mu \mathrm{l}$, $20 \mathrm{mM}$ Tris- $\mathrm{Cl}$ (pH 7.4), $7.5 \mathrm{mM}$ magnesium acetate, $25 \mu \mathrm{M}\left[\gamma_{-}{ }^{32} \mathrm{P}\right] \mathrm{ATP}$ $\left(1-2 \times 10^{2} \mathrm{cpm} / \mathrm{pmol}\right), 750 \mu \mathrm{g}$ of histone $\mathrm{H1}, 12.5 \mu \mathrm{g}$ bovine serum albumin, $1 \mathrm{mM} \mathrm{CaCl}, 0.5 \mathrm{mM}$ dithiothreitol, $8 \mu \mathrm{g}$ of PS, and protein kinase $\mathrm{C}$. Incubations were carried out in $1.5-\mathrm{ml}$ tubes for $5 \mathrm{~min}$ at $30^{\circ} \mathrm{C}$. Immediately after incubation the tubes were placed on ice, aliquots $(25 \mu \mathrm{l})$ were spotted onto $2 \times 2-\mathrm{cm}$ squares of phosphocellulose paper, and the paper was washed three times in water, rinsed in acetone, then in petroleum ether, and dried (19). Radioactivity was assayed in 4 $\mathrm{ml}$ of Aquasol (New England Nuclear).

Protein kinase $\mathrm{C}$ was purified from mouse brain. Preparation of brain cytosol and chromatography on DEAE-cellulose was carried out by a modification of the procedure of Kikkawa and co-workers (20). Further fractionation was by chromatography over a Blue Sepharose column. The peak of activity from the Blue Sepharose column was chromatographed on a Mono $\mathrm{Q}$ strong anion exchange column (Pharmacia Fine Chemicals) in the presence of $1 \mathrm{mM}$ ATP and eluted with a salt gradient. Final purification was achieved by hydrophobic chromatography on a Phenyl 5-PW column (Bio-Rad Laboratories, Richmond, CA). Protein was determined by the method of Bradford (21). The enzymatic activity was stabilized in the presence of $0.01 \%$ Triton X-100, and the enzyme was stored at $-70^{\circ} \mathrm{C}$.

The specific enzymatic activity of the purified preparations averaged $2.1 \pm 0.3 \mu \mathrm{mol}$ phosphate transferred per milligram per minute. The kinase activity assayed in the absence of calcium and PS was $4.5 \pm 2.3 \%$ of that in their presence. The specific $\left[{ }^{3} \mathrm{H}\right] \mathrm{PDBu}$ binding activity was $7,300 \pm 1,200 \mathrm{pmol} / \mathrm{mg}$. In terms of binding activity, the purification relative to cytosol was 260 -fold. Because of the presence in cytosol of inhibitors of the enzymatic activity, the fold purification of the enzymatic activity could not be accurately determined. Upon SDS gel electrophoresis and silver staining, the kinase was $>95 \%$ pure. For comparison, the activity of protein kinase $C$ purified from rat brain by Kikkawa et al. (20) was $1.09 \mu \mathrm{mol}$ phosphate/mg per min. Details of the purification will be published elsewhere (Jeng and Blumberg, manuscript in preparation).

\section{Results}

Neutrophil phorbol ester receptor. We have previously studied the relationship of phorbol ester binding to expression of the human neutrophil NADPH-oxidase (4). The similarity between the potencies of PMA and PDBu for stimulation of the oxidase and for binding to the phorbol ester receptors argued for linkage between receptor-ligand interactions and stimulation of the NADPH-oxidase. In the present studies we further explore the relationship of the phorbol ester receptor to the constituents of the oxidase.

Most of the specific $\left[{ }^{3} \mathrm{H}\right] \mathrm{PDBu}$ binding was found in the cytosolic fraction of unstimulated, nitrogen-cavitated neutro- 
phils; at $\sim 20 \mathrm{nM}\left[{ }^{3} \mathrm{H}\right] \mathrm{PDBu}$, the specific binding activity was $8.6 \pm 1.7 \mathrm{pmol} / \mathrm{mg}$ protein $(n=3)$. That for the $\gamma-, \beta$-, and $\alpha$ fractions was considerably lower, approaching the limits for measurement. Specific activities were $0.86 \pm 0.09(n=3)$, $0.29 \pm 0.11(n=4)$, and $0.11 \pm 0.03(n=4) \mathrm{pmol} / \mathrm{mg}(\mathrm{mean} \pm \mathrm{SE}$ for $n$ experiments), respectively. After correction for the relative amounts of protein in each fraction, the percentages of total binding activity were $94.7,3.0,1.5$, and $0.4 \%$ for the $S_{2}, \gamma$-, $\beta$-, and $\alpha$-fractions, respectively. The recovery of binding activity, based on a single determination of activity in the neutrophil cavitate, was $\sim 45 \%$. The $K_{d}$ for $\left[{ }^{3} \mathrm{H}\right] \mathrm{PDBu}$ binding to the cytosolic fraction reconstituted with PS was determined by Scatchard analysis to be $1.2 \pm 0.3 \mathrm{nM}(n=3)$ (Fig. 1). This value is similar to that $(0.8 \mathrm{nM})$ determined by us for the partially purified receptors from mouse brain cytosol. This affinity is considerably higher than that which we had observed in intact cells (38 nM) (4). We presume this difference in affinity reflects the reconstitution of the receptor in PS rather than the actual phospholipids of the neutrophil membranes. In the case of the cytosolic receptor from brain, we had earlier reported a 30 -fold difference in affinity for the receptor reconstituted in PS and in an erythrocyte phospholipid mixture (22).

No significant difference was found in the distribution of the binding activity between the subcellular fractions of control and stimulated neutrophils. Levels of binding for the postcentrifugation cytosol and for the $\gamma$-, $\beta$-, and $\alpha$-fractions were 8.8 \pm 2.0 , $0.78 \pm 0.20,0.21 \pm 0.10$, and $0.08 \pm 0.01 \mathrm{pmol} / \mathrm{mg}$ protein, respectively (mean \pm range, $n=2$ ). Since phorbol ester treatment has been reported to induce changes in apparent protein kinase C distribution in neutrophils (17) and some other systems (23, 24) under other lysis conditions, we presume that our findings reflect the extractability of the potentially redistributed receptors under our fractionation conditions. It is of note that in the current studies, we have separated the cell into density compartments, used DFP-treated cells, and employed calcium chelators throughout the harvesting of the various components.

Characterization of NADPH-oxidase activation by PMA. Based on these binding studies of phorbol ester, we endeavored to determine the functional correlation with NADPH-oxidase expression. Previous studies have shown that the membrane bound NADPH-oxidase may be activated in a broken cell cell

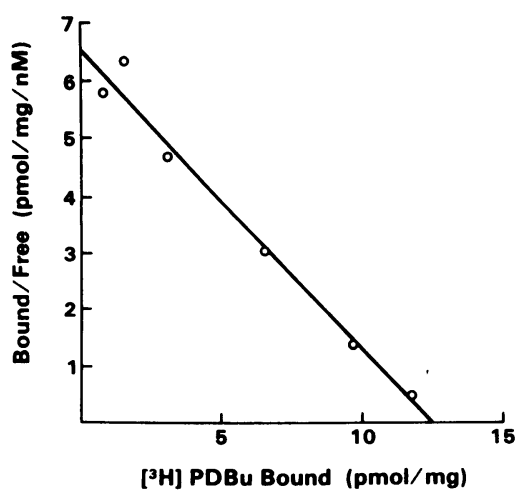

Figure 1. Scatchard analysis of $\left[{ }^{3} \mathrm{H}\right] \mathrm{PDBu}$ binding to the postcentrifugation supernatant $\left(\mathrm{S}_{2}\right)$ fraction from unstimulated neutrophils. $\left[{ }^{3} \mathrm{H}\right] \mathrm{PDBu}$ binding was assayed as described in Methods using $170 \mu \mathrm{g}$ protein/tube. Points represent the average of triplicate determinations in a single experiment. Two other experiments yielded similar results.
Table I. Conditions for Reconstitution

of NADPH-Oxidase Activity

\begin{tabular}{ll}
\hline $\mathrm{S}_{2}^{*}$ & PK-C* \\
\hline nmoles $O_{2}^{-} /$min/mg & $\gamma$-fraction
\end{tabular}

NADPH-oxidase reconstituted

system

No omissions

$10.35 \pm 0.73$

$8.5 \pm 0.10$

Omit:

PK-C

$\mathrm{S}_{2}$ fraction

$-$

PS

$1.40 \pm 0.43$

$0.98 \pm 0.14$

PMA

$0.38 \pm 0.07$

ATP

$1.30 \pm 0.26$

$0.18 \pm 0.31$

$\gamma$-fraction

$4.36 \pm 0.50 \ddagger$

$1.86 \pm 0.75$

$\mathrm{Ca}^{++}$(EGTA, $2 \mathrm{mM}$, added)

$1.80 \pm 0.62$

$0.98 \pm 0.13$

$\mathrm{Mg}^{++}$

$2.90 \pm 1.01$

$1.04 \pm 0.66$

$1.68 \pm 0.55$

$0.91 \pm 0.32$

* Experimental conditions for assay of NADPH-oxidase are detailed in Methods. The data presented are the mean \pm SD of three experiments. $S_{2}$ reconstitution employs the cytosol sub-fraction, and protein kinase C (PK-C) employs 4 U of purified PK-C in lieu of $S_{2}$. $\ddagger P<0.005$; all other omissions are significant at least at $P<0.001$.

system by the addition of AA to a cytosolic factor (15-17). We have extended those initial studies by characterizing the pathway of oxidase activation through the protein kinase C system. PMA alone was unable to stimulate the oxidase in nitrogen-cavitated neutrophils when tested at concentrations corresponding approximately to 50 -fold the $K_{\mathrm{d}}$ for the phorbol ester receptor; however, under specific conditions appropriate for protein kinase $C$ activation, namely inclusion of PMA, phospholipid, ATP, and a cytosolic factor, the NADPH-oxidase was activated.

In these studies, separation of the cytosol $\left(\mathrm{S}_{2}\right)$ fraction and a light membrane fraction ( $\gamma$-fraction), the site of NADPH-oxidase in prefractionated PMA-stimulated neutrophils (18), enabled us to define the basic requirements of the reconstituted oxidase system. PMA added to a mixture of $S_{2}, P S(160 \mu \mathrm{g} / \mathrm{ml})$, and ATP $(50 \mu \mathrm{M})$ did not generate appreciable quantities of $\mathrm{O}_{2}^{-}$, but when the $\gamma$-fraction was added to this mixture, the system generated $10.75 \pm 2.2 \mathrm{nmol} / \mathrm{mg} \gamma$-protein per minute (mean $\pm \mathrm{SD}, n=6$ separate neutrophil preparations) (Table I). In the absence of $S_{2}$ or phospholipid, this system did not generate significant quantities of $\mathrm{O}_{2}^{-}$(Table I). The dose responsiveness of the reconstitution system for PS is shown in Fig. 2. In our coupled assay, the dependence of oxidase activation on particular phospholipids paralleled that for protein kinase $\mathrm{C}$ studied in other tissues (Fig. 2) (8), in that PI was as effective as PS in reconstituting activity, whereas phosphatidylethanolamine and phosphatidylcholine were ineffective in the concentration range affecting phorbol binding (data not shown) (8). While some oxidase activity was expressed when exogenous ATP was omitted from the $S_{2}$ reaction mixture (presumably due to endogenous ATP of $S_{2}$ ), inhibition was still highly significant (Table I). It should be noted that the disruption buffer, and thus the $S_{2}$ fraction, but not the resuspended $\gamma$-fraction, contained added $\mathrm{MgCl}_{2}$ and ATP, thus the omission of these constitutents from the final assay mixture was not complete; however, significant reduction of NADPH-oxidase activity with their respective omissions $\left(P<0.001\right.$ for $\mathrm{Mg}^{++}$and $P<0.005$ for ATP) is noted (Table I) 


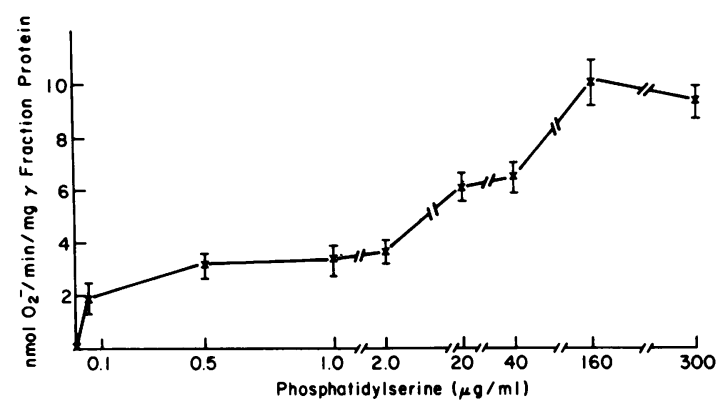

Figure 2. Phospholipid dependence of NADPH-oxidase activation. NADPH-oxidase activity is expressed as $\mathrm{O}_{2}^{-}$generated and is detailed in Methods. Varying concentrations of PS were incubated with $330 \mu \mathrm{g}$ $\mathrm{S}_{2}, 200 \mu \mathrm{g} \gamma$-fraction protein, ATP $(50 \mathrm{nmol})$, cytochrome $c$ (80 $\mathrm{nmol})$, NADPH (100 nmol), and $1 \mathrm{ng}$ of PMA. The data are a representative experiment (three performed) of a single neutrophil subfractionation preparation and expressed as mean $\pm \mathrm{SD}$ of three assays at each phospholipid concentration.

and is consistent for the co-factor requirements of protein kinase C (8). The calcium dependence of the reaction could only be demonstrated with the addition of EGTA ( $2 \mathrm{mM}$ ) (Table I), since omitting calcium did not depress oxidase activity in the reconstituted system (data not shown). Residual calcium in the cytoplasm and leached membrane calcium from the $\gamma$-fraction (sic infra) may have been sufficient for reconstitution of activity.

The dose-response curve for PMA (Fig. 3) revealed a halfmaximally effective dose of $1.1 \pm 0.2 \mathrm{nM}$ (determined by least square analysis from double reciprocal plots of three experiments), which was consistent with the high affinity of PMA for protein kinase $C(7)$ and the measured amount of protein kinase $\mathrm{C}$ in the $\mathrm{S}_{2}$ preparations. When OAG $(20 \mu \mathrm{g} / \mathrm{ml})$ was substituted for PMA, 8.6 $\pm 2.2 \mathrm{nmol} \mathrm{O}-/ \mathrm{min}$ per $\mathrm{mg} \gamma$-fraction was generated; since incubation of OAG without $S_{2}$ generated only $0.6 \pm 0.8$ $\mathrm{nmol} \mathrm{O}_{2}^{-} / \mathrm{min}$ per $\mathrm{mg} \gamma$-fraction, it appears that OAG, like PMA, reconstitutes cytosolic protein kinase $C(8)$, not the oxidase di-

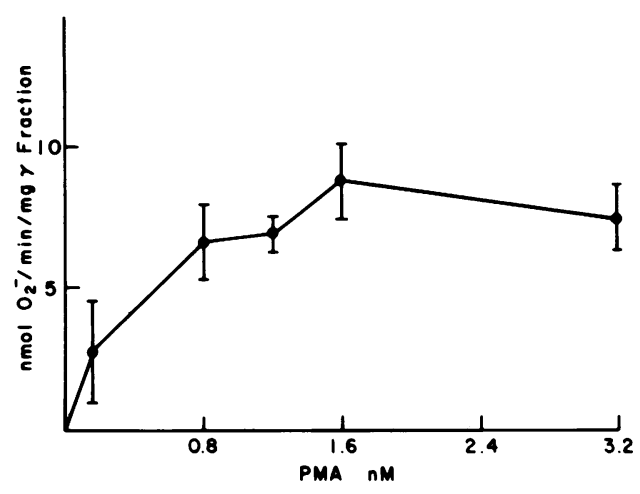

Figure 3. PMA dose response of NADPH-oxidase activation. NADPH-oxidase activity is expressed as $\mathrm{O}_{2}^{-}$generated and detailed in Methods. Varying concentrations of PMA were added to $220 \mu \mathrm{g}$ of $\gamma$ fractions and $430 \mu \mathrm{g}$ of $S_{2}$ fractions in the presence of PS $(160 \mu \mathrm{g})$ and ATP $(50 \mathrm{nmol})$, and were incubated at $28^{\circ} \mathrm{C}$ for $1 \mathrm{~min}$. NADPH (100 nmol) and cytochrome $c(80 \mathrm{nmol})$ were then added and $\mathrm{O}_{2}^{-}$generation was monitored at $28^{\circ} \mathrm{C}$. The data are a representative experiment (three performed) of a single neutrophil subfractionation preparation and are expressed as mean \pm SD of three assays at each PMA concentration; other experiments gave similar results.

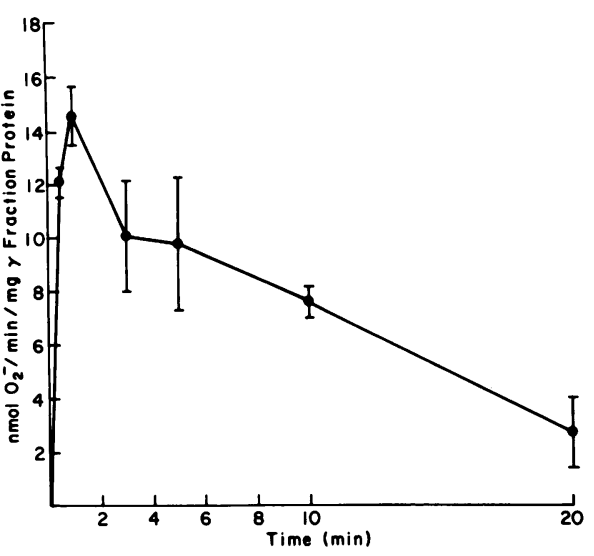

Figure 4. Time course for NADPH-oxidase activation. NADPH-oxidase activity is expressed as $\mathrm{O}_{2}^{-}$generated and is detailed in Methods. PMA (1 ng), ATP (50 nmol), $200 \mu \mathrm{g} \gamma$-fraction, $300 \mu \mathrm{g} \mathrm{S}$, and $160 \mu \mathrm{g}$ PS were incubated at $28^{\circ} \mathrm{C}$ for varying periods (as indicated on the abscissa), and then NADPH-oxidase activity was assessed with the addition of NADPH $(100 \mathrm{nmol})$ and cytochrome $c(80 \mathrm{nmol})$. The data are a representative experiment (three performed) of a single neutrophil subfractionation preparation and are expressed as mean \pm SD of three assays at each time point.

rectly nor sufficient quantities of the small amount of protein kinase $C$ associated with the $\gamma$-fraction.

These studies were conducted under optimal experimental conditions. To assess the time course required for incubating $\mathrm{S}_{2}, \gamma$-fraction, ATP, PMA, and PS together to form an oxidaseactivating mixture, experiments were conducted where the mixture was incubated for varying times, followed by addition of NADPH and cytochrome $c$, and immediate assay of oxidase expression. Activation of the oxidase was maximal when the $\gamma$ fraction and $S_{2}$ reconstitution mixture were preincubated for 1 min, and by 20 min of $S_{2}-\gamma$ preincubation only $20 \%$ of the oxidase-stimulating activity remained (Fig. 4). Subsequently, all protein kinase $\mathrm{C}$ reconstitution studies were performed with 1 min preincubations, at a $\mathrm{pH}$ of 7.0 , within the optimum $\mathrm{pH}$ range for the protein kinase $\mathrm{C}$ reconstitution studies (data not shown), which also corresponds to the $\mathrm{pH}$ optimum of the NADPH-oxidase (5). Both $\mathrm{S}_{2}$ and $\gamma$-fractions could be stored at $-70^{\circ} \mathrm{C}$ for up to 2 mo without losing their respective activities (data not shown).

When $4 \mathrm{U}$ of purified protein kinase $\mathrm{C}$ (each unit equals 500 pmol $\mathrm{PO}_{4}^{-}$transfered/min) was substituted for $\mathrm{S}_{2}$, the membranous $\gamma$-fraction generated $8.6 \pm 0.7 \mathrm{nmol} \mathrm{O}_{2}^{-} / \mathrm{min}$ per $\mathrm{mg} \gamma$-protein (mean $\pm \mathrm{SD}, n=3$ ) with a time course of $\mathrm{O}_{2}^{-}$production similar to that previously reported for NADPH-oxidase activity harvested from intact PMA-stimulated cells (Fig. 5) (25). The generation of $\mathrm{O}_{2}^{-}$showed a dose response with the amount of protein kinase $\mathrm{C}$ added over the range of $0.5-6 \mathrm{U}$. Protein kinase $\mathrm{C}$ at $2 \mathrm{U}$ gave $73 \%$ of the maximal stimulation, and at the highest effective concentration (4-6 U) accounted for $80 \pm 3.5 \%$ (mean $\pm \mathrm{SD}, n=3$ ) of the $\mathrm{S}_{2}$ activity of the $\mathrm{O}_{2}^{-}$generating reconstituted system (Fig. 6). Higher concentrations of protein kinase $C$ were not examined because of lack of material. Quantitatively, the levels of protein kinase $C$ in the systems reconstituted with $S_{2}$ and the purified enzyme give reasonable agreement. As determined from the level of phorbol ester binding in the $\mathrm{S}_{2}$ fraction (see above), $450 \mu \mathrm{g}$ of $\mathrm{S}_{2}$ should contain $3.9 \mathrm{pmol}$ of kinase, which corresponds to $2.2 \mathrm{U}$ of protein kinase $\mathrm{C}$ activity. 


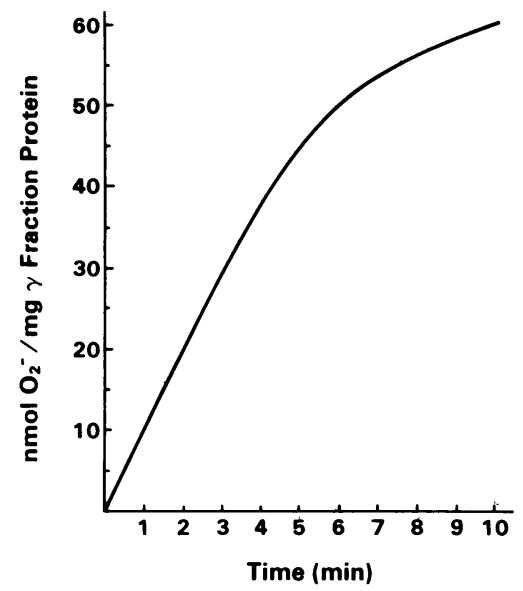

Figure 5. Time course of $\mathrm{O}_{2}^{-}$production by NADPH-oxidase activated by purified protein kinase $\mathrm{C}$. NADPH-oxidase activity is expressed as $\mathrm{O}_{2}^{-}$generated and is detailed in Methods. The incubation mixture of PMA (1 ng), PS (160 ng), ATP (50 nmol), protein kinase C (4 U), and of $\gamma$-fraction $(200 \mu \mathrm{g})$ was incubated for $1 \mathrm{~min}$ at $28^{\circ} \mathrm{C}$, and then NADPH $(100 \mathrm{nmol})$ and cytochrome $c(80 \mathrm{nmol})$ were added and $\mathrm{O}_{2}^{-}$ generation monitored at $28^{\circ} \mathrm{C}$. The time course is a representative experiment of nine similarly performed.

The $\gamma$-fraction alone $(220 \mu \mathrm{g})$ should contain $\sim 0.1 \mathrm{U}$ of activity, accounting for the requirement for exogenously added protein kinase $\mathrm{C}$.

Activation using the purified protein kinase $\mathrm{C}$ showed similar requirements to the reconstituted system using $S_{2}$ (Table I). The oxidase activity was not expressed when denatured protein was substituted for the $\gamma$ or $S_{2}$ fractions (fractions were boiled for 5 $\min$ ) or when NADPH was omitted from the reaction mixture (Table I). The calcium dependence could only be demonstrated when EGTA $(2 \mathrm{mM})$ was added to the reaction buffer, which presumably reflected the low calcium concentration required for kinase reconstitution. The low calcium concentrations needed for protein kinase $\mathrm{C}$ expression in the presence of the phorbol esters has been previously noted $(25,26)$ (see Dicussion). That the source of the $\mathrm{O}_{2}^{-}$was the NADPH-oxidase was indicated by the same pH optimum (7.0) and $K_{\mathrm{m}}$ for NADPH, $19 \mu \mathrm{M}$, as had previously been shown for the particulate and solubilized preparations from PMA-stimulated neutrophils $(5,27)$.

\section{Discussion}

The activation of the human neutrophil by PMA leads to a spectrum of responses, including aggregation (28), stimulation of the respiratory burst (1, 4-7), degranulation of specific granules (29), depolarization of the plasma membrane, and enhanced phospholipid turnover (30). These effects appear to be initiated by a mechanism that does not involve the usual receptors oriented on the external face of the plasma membrane as deduced from the findings that several of PMA's stimulatory effects are impervious to chemical modification of the external membrane surface $(5,6)$ and the recent finding that, unlike most other agonists, PMA-evoked responses are not associated with elevated intracellular calcium levels (31). The diversity of the neutrophil responses suggests that PMA initiates its various actions by complex and hierarchyl systems. We have endeavored to examine one of these responses, namely stimulation of the NADPH-oxidase. In this report, we have extended our initial phorbol ester binding studies, and we have demonstrated that we can recon- stitute the phorbol ester mediated pathway for activation of the NADPH-oxidase in a partially purified in vitro system. The activity so constituted conforms to the biochemical criteria for the NADPH-oxidase; although the specific activity is low, $\sim 10 \mathrm{nmol}$ $\mathrm{O}_{2}^{-} / \mathrm{mg}$ protein per min, this is higher than that reported for arachidonic acid stimulation (17) and similar to our previous study of this oxidase in particulate $(5,27)$ and light membrane preparations (18).

The binding studies demonstrate similar characteristics for the cytosolic form of the human neutrophil receptor as compared with that from mouse brain. Thus, dissociation constants for $\left[{ }^{3} \mathrm{H}\right] \mathrm{PDBu}$ binding were the same within experimental limits and thus consonant with the very great degree of conservation of receptor binding characteristics over evolution; we had earlier reported that binding to nematodes and to mouse skin were almost indistinguishable (32).

Several groups have studied the activation of the NADPHoxidase in a broken cell preparation by oleate (14) or AA (1517). These reports suggest that a soluble factor is involved in activating the membrane-bound oxidase. Earlier studies suggested that the NADPH-oxidase is localized in the plasma membrane in cells stimulated before fractionation, and we characterized this distribution in Percoll gradients, where the activity localizes in a light membrane fraction, the so-called $\gamma$-fraction (18). We have shown that while some oxidase constituents are in place in the resting cell, PMA initiates a recruitment of NADPH-oxidase constituents from the specific granule pool, which at least in PMA-stimulated cells parallels activity (18). From the studies reported here, we have demonstrated that the NADPH-oxidase of the $\gamma$-fraction may be activated by a cytoplasmic factor to generate $\mathrm{O}_{2}^{-}$, and that the constituents of the $\beta$-fraction (specific granules) are not required. Nonetheless, recruitment of the $\beta$-fraction constituents is probably necessary for maximal expression in the intact cell, especially when invagination of plasma membrane into phagocytic vacuoles and auto-inactivation of the oxidase (25) are taken into account.

The soluble factor required for reconstitution appears to be protein kinase $C$, based on its biochemical requirements for specific phospholipids, PMA, and ATP, and the loss of activity in the presence of the calcium chelator EGTA. Although addition of external calcium was not required in the presence of PMA,

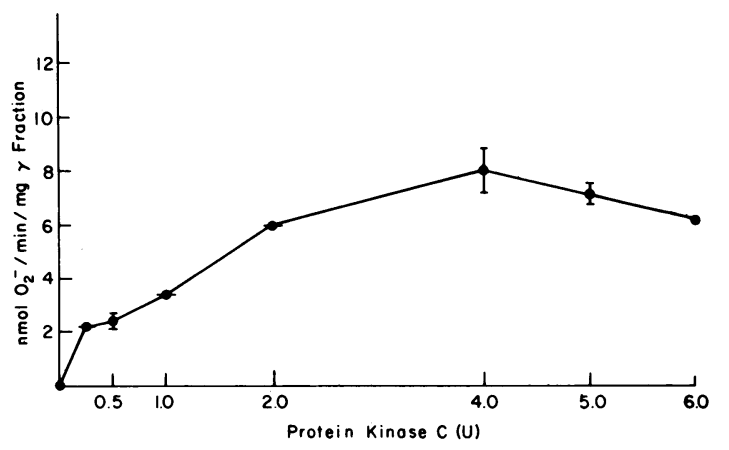

Figure 6. Protein kinase $\mathrm{C}$ dose response for activation of the NADPH-oxidase. NADPH-oxidase activity is expressed as $\mathrm{O}_{2}^{-}$generated and detailed in Materials and Methods. The data are a representative experiment where the indicated amounts of protein kinase $\mathrm{C} \mathrm{(1}$ $\mathrm{U}=500 \mathrm{pmol} \mathrm{PO}_{4}^{-}$transfered $/ \mathrm{min}$ ) were incubated with $220 \mu \mathrm{g}$ of $\gamma-$ fraction, PMA (i ng), PS (160 ng) and ATP ( $50 \mathrm{nmol})$ for $1 \mathrm{~min}$ at $28^{\circ} \mathrm{C}$. The data are a representative experiment (three performed) of a single neutrophil subfractionation preparation. 
this result may reflect the extremely low concentration that suffices under these conditions $(25,26,33)$. Thus, only by omitting calcium in the reaction mixture and adding the calcium chelator EGTA was the calcium dependence demonstrated. It should be noted that the addition of PE, but not PS, augments the expression of NADPH-oxidase in Triton-solubilized preparations (34), but phospholipids are without effect in our study without the addition of all of the other constituents of the protein kinase $C$ system: thus, PI and PS directly augment protein kinase activity, not the oxidase. In most other systems examined, phosphorylation of membranes by exogenous or endogenous protein kinase $\mathrm{C}$ similarly is dependent on addition of exogenous anionic phospholipids (see references 35 and 36 as examples). This dependence on exogenous phospholipid presumably reflects the difference in composition of the natural membranes and the high level of protein present in them. The reconstitution analysis indicates that activation of the NADPH-oxidase activity in the light membrane fraction requires the addition of cytosol. The analysis of the phorbol ester binding activity of the subcellular fractions accounts for this requirement. The specific activity of protein kinase $\mathrm{C}$ in the $\gamma$-fraction is only $10 \%$ of that in $\mathrm{S}_{2}$ fraction and accounts for only $3 \%$ of the total phorbol ester binding.

The fractionation experiments cannot resolve whether protein kinase $C$ is associated with the $\gamma$-fraction in the intact resting or activated neutrophil. Protein kinase $\mathrm{C}$ associates with phospholipid bilayers in vitro as a function of phospholipid composition, divalent cation concentration, and the presence of phorbol esters or diacylglycerols (8), parameters which may be perturbed in vivo during cell activation. Antibody localization studies at the electron microscopic level are therefore needed to determine the relationship between the in vivo distributions and those found after various fractionation protocols.

These studies open the way to defining the pathway by which the phorbol esters stimulate the human neutrophil. Characterization of the phosphorylation products of the protein kinase $\mathrm{C}$ should provide identification of either "activation" proteins, which are part of a more complex activation sequence, or of the NADPH-oxidase complex itself, which may become active once one or more of its constituents are phosphorylated. Our work suggests that phosphorylation of the $\gamma$-fraction membrane-bound oxidase is the likeliest site of protein kinase $\mathrm{C}$ control, and thus we are currently examining phosphorylation products in this subcellular compartment.

\section{Acknowledgments}

The authors gratefully acknowledge the expert secretarial services of Ms. Ann Marie Happnie.

This research has been supported in part by National Institutes of Health grants AI20064 and HL33565.

\section{References}

1. Repine, J. E., J. G. White, C. C. Clawson, and B. M. Holmes. 1974. The influence of phorbol myristate acetate on oxygen consumption by polymorphonuclear leukocytes. J. Lab. Clin. Med. 83:911-920.

2. Badwey, J. A., J. T. Curnutte, and M. L. Karnovsky. 1982. cisPolyunsaturated fatty acids induce high levels of superoxide production by human neutrophils. J. Biol. Chem. 256:12640-12643.

3. Tauber, A. I., N. Borregaard, E. Simons, and J. Wright. 1983. Chronic granulomatous disease: a syndrome of phagocyte oxidase deficiencies. Medicine. 62:286-309.
4. Tauber, A. I., D. B. Brettler, E. A. Kennington, and P. M. Blumberg. 1982. Relation of human neutrophil phorbol ester receptor occupancy and NADPH-oxidase activity. Blood. 60:333-339.

5. Tauber, A. I., and E. J. Goetzl. 1979. Structural and catalytic properties of the solubilized superoxide-generating activity of human polymorphonuclear leukocytes. Solubilization, stabilization in solution, and partial characterization. Biochemistry. 18:5576-5584.

6. Tauber, A. I., and E. J. Goetzl. 1981. Inhibition of complementmediated functions of human neutrophils by impermeant stilbene disulfonic acids. J. Immunol. 126:1786-1789.

7. Leach, K. L., M. L. James, and P. M. Blumberg. 1983. Characterization of a specific phorbol ester aporeceptor in mouse brain cytosol. Proc. Natl. Acad. Sci. USA. 80:4208-4212.

8. Blumberg, P. M., J. A. Dunn, S. Jaken, A. Y. Jeng, K. L. Leach, N. A. Sharkey, and E. Yeh. 1984. Specific receptors for phorbol ester tumor promoters and their involvement in biological responses. CRC Tumor Promotion Handbook. CRC Press, Boca Raton. 143-184.

9. Schneider, C., M. Zanetti, and D. Romeo. 1981. Surface-reactive stimuli selectively increase protein phosphorylation in human neutrophils. FEBS. (Fed. Eur. Biochem. Soc.) Lett. 127:4-8.

10. Andrews, P. C., and B. M. Babior. 1983. Endogenous protein phosphorylation by resting and activated human neutrophils. Blood. 61 : 333-340.

11. Helfman, D. M., B. D. Appelbaum, N. R. Volger, and J. F. Kuo. 1983. Phospholipid-sensitive $\mathrm{Ca}^{2+}$-dependent protein kinase and its substrates in human neutrophils. Biochem. Biophys. Res. Commun. 111: 847-853.

12. White, J. R., C. K. Huang, J. M. Hill, P. H. Naccache, E. L. Becker, and R. I. Sha'afi. 1984. Effect of phorbol 12-myristate 13-acetate and its analogue 4 phorbol 12,13-didecanoate on protein phosphorylation and lysosomal enzyme release in rabbit neutrophils. J. Biol. Chem. 259: 8605-8611.

13. McPhail, L. C., C. L. Clayton, and R. Snyderman. 1984. A potential second messenger role for unsaturated fatty acids: activation of $\mathrm{Ca}^{2+}$-dependent protein kinase. Science (Wash. DC). 224:622-625.

14. Heyneman, R. A., and R. E. Vercauteren. 1984. Activation of a NADPH-oxidase from horse polymorphonuclear leukocytes in a cellfree system. J. Leuk. Biol. 36:751-759.

15. Bromberg, Y., and E. Pick. 1984. Unsaturated fatty acids stimulate NADPH-dependent superoxide production by cell-free system derived from macrophages. Cell. Immunol. 88:213-221.

16. Curnutte, J. T. 1985. Activation of human neutrophil NADPH oxidase by arachidonic acid in a cell-free system. J. Clin. Invest. 75 : 1740-1743.

17. McPhail, L. C., P. S. Shirley, C. C. Clayton, and R. Snyderman. 1985. Activation of the respiratory burst enzyme from human neutrophils in a cell-free system: evidence for a soluble co-factor. J. Clin. Invest. 75: 1735-1739.

18. Borregaard, N., and A. I. Tauber. 1984. Subcellular localization of the human neutrophil NADPH-oxidase: b cytochrome and associated flavoprotein. J. Biol. Chem. 259:47-52.

19. Wịtt, J. J., and R. J. Roskowski. 1975. Rapid protein kinase assay using phosphocellulose-paper absorption. Anal. Biochem. 66:253-258.

20. Kikkawa, N., Y. Takai, R. Minakuchi, S. Inohara, and Y. Nishizuka. 1982. Calcium-activated, phospholipid-dependent protein kinase from rat brain. Subcellular distribution, purification, and properties. $J$. Biol. Chem. 257:13341-13348.

21. Bradford, M. M. 1976. A rapid and sensitive method for the quantitation of microgram quantities of protein utilizing the principle of protein-dye binding. Anal. Biochem. 72:248-254.

22. Blumberg, P. M., S. Jaken, B. Konig, N. A. Sharkey, K. L. Leach, A. Y. Jeng, and E. Yeh. 1984. Mechanism of action of the phorbol ester tumor promoters: specific receptors for lipophilic ligands. Biochem. Pharmacol. 33:933-940.

23. Kraft, A. S., and W. B. Anderson. 1983. Phorbol esters increase the amount of $\mathrm{Ca}^{++}$, phospholipid-dependent protein kinase associated with plasma membrane. Nature (Lond.). 301:621-623.

24. Kraft, A. S., W. B. Anderson, H. L. Cooper, and J. J. Sando. 
1982. Decrease in cytosolic calcium/phospholipid-dependent protein kinase activity following phorbol ester treatment of EL4 thymoma cells. J. Biol. Chem. 257:13193-13196.

25. Niedel, J. E., L. J. Kuhn, and G. R. Vandenbark. 1980. Phorbol ester receptor co-purifies with protein kinase C. Proc. Natl. Acad. Sci. USA. 80:36-40.

26. DiVirgilio, F., D. P. Lew, and T. Pozzan. 1984. Protein kinase $\mathrm{C}$ activation of physiological processes in human neutrophils at vanishingly small cytosolic $\mathrm{Ca}^{++}$levels. Nature (Lond.). 310:691-693.

27. Light, D. R., C. Walsh, A. M. O'Callaghan, E. J. Goetzl, and A. I. Tauber. 1981. Characteristics of the cofactor requirements for the $\mathrm{O}_{2}^{-}$-generating NADPH-oxidase of human polymorphonuclear leukocytes. Biochemistry. 20:1468-1476.

28. O'Flaherty, J. T., L. R. DeChatelet, C. E. McCall, and D. A. Bass. 1980. Neutrophil aggregation: evidence for a different mechanism of action by phorbol myristate acetate. Proc. Soc. Exp. Biol. Med. 165: 225-232.

29. Smith, G. P., and T. J. Peters. 1982. The release of granule components from human polymorphonuclear leukocytes in response to both phagocytic and chemical stimuli. Biochim. Biophys. Acta. 719:304-308.

30. Tauber, A. I., and E. R. Simons. 1983. Dissociation of human neutrophil membrane depolarization, respiratory burst stimulation, and phospholipid metabolism by quinacrine. FEBS (Fed. Eur. Biochem. Soc.) Lett. 156:161-164.

31. Pozzan, T., D. P. Lew, C. B. Wollheim, and R. Y. Tsien. 1983. Is cytosolic ionized calcium regulation neutrophil activation? Science (Wash. DC). 221:1413-1415.

32. Blumberg, P. M., K. B. Delclos, and S. Jaken. 1983. Tissue and species specificity for phorbol ester receptors. In Organ and Species Specificity in Chemical Carcinogenesis. R. Langenbach, S. Nesnow, and J. M. Rice, editors. Plenum Publishing Co., New York. 201-229.

33. Arcoleo, J. P., and I. B. Weinstein. 1985. Activation of protein kinase $\mathrm{C}$ by tumor promoting phorbol esters, teleocidin and aplysiatoxin in the absence of added calcium. Carcinogenesis. 6:213-217.

34. Gabig, T. G., and B. M. Babior. 1979. The $\mathrm{O}_{2}^{-}$-forming oxidase responsible for the respiratory burst in human neutrophils, properties of the solubilized enzyme. J. Biol. Chem. 254:9070-9074.

35. Iwasa, Y., and M. M. Hosey. 1984. Phosphorylation of cardiac sarcolemma proteins. The calcium-activated phospholipid-dependent protein kinase. J. Biol. Chem. 259:534-540.

36. Wrenn, R. W., N. Katoh, B. C. Wise, and J. F. Kua. 1980. Stimulation by phosphatidylserine and calmodulin of calcium-dependent phosphorylation of endogenous proteins from cerebral cortex. J. Biol. Chem. 255:12042-12046. 